\title{
Characterization of Wheatgrass-Derived Barley Yellow Dwarf Virus Resistance in a Wheat Alien Chromosome Substitution Line
}

\author{
Joseph M. Anderson, Dennis L. Bucholtz, Ann E. Greene, Michael G. Francki, \\ Stewart M. Gray, Hari Sharma, Herbert W. Ohm, and Keith L. Perry
}

\begin{abstract}
First, second, and third authors: USDA-ARS, Purdue University, 1150 Lilly Hall, West Lafayette, IN 47907-1150; fifth author: USDA-ARS, Cornell University, Ithaca, NY 14853-0331; first, fourth, sixth, and seventh authors: Agronomy Department, Purdue University, 1150 Lilly Hall, West Lafayette, IN 47907-1150; and eighth author: Botany and Plant Pathology Department, Purdue University, 1155 Lilly Hall, West Lafayette, IN 47907-1155.
\end{abstract}

Accepted for publication 27 May 1998.

\begin{abstract}
Anderson, J. M., Bucholtz, D. L., Greene, A. E., Francki, M. G., Gray, S. M., Sharma, H., Ohm, H. W., and Perry, K. L. 1998. Characterization of wheatgrass-derived barley yellow dwarf virus resistance in a wheat alien chromosome substitution line. Phytopathology 88:851-855.

Wheatgrass (Thinopyrum intermedium) possesses a high level of resistance to barley yellow dwarf virus (BYDV) subgroup I and subgroup II strains. A wheat line (P29), in which the 7D chromosome has been substituted with a group 7 chromosome from $T$. intermedium, was examined for the level of resistance to two subgroup I and two subgroup II BYDV strains. In P29 plants inoculated with the subgroup I PAV strains, the titer

virus in inoculated T. intermedium plants indicate that the complete resistance to subgroup I possessed by the wheatgrass has not been introgressed into P29. In contrast, P29 was completely resistant throughout the plant to the subgroup II strains, NY-RPV and NY-RMV, demonstrating that the complete resistance to subgroup II in T. intermedium was incorporated into P29. Further analysis of this resistance to NY-RPV showed that NYRPV can replicate in mesophyll protoplasts of P29 and 'Abe', suggesting that this resistance is not operating at the single-cell level. Molecular marker analysis confirmed that the T. intermedium chromosome present in P29 is a different group 7 wheatgrass chromosome than that present in L1, a wheat line with BYDV resistance properties similar to those of P29.
\end{abstract} of virus in leaf and stem tissue was typically reduced 42 to $52 \%$ when compared with the BYDV-susceptible cv. Abe. P29 and 'Abe' had the same content of PAV in roots. These results and the absence of detectable
Additional keywords: wide crosses, resistance breeding.

tance from wheatgrass into wheat through interspecific crosses $(2$, $8,19,32,33,40)$.

Sharma et al. (32) produced intergeneric hybrids of wheat (Triticum aestivum) $\times$ intermediate wheatgrass (Thinopyrum intermedium) crosses and backcrossed resistance into wheat lines with a $2 \mathrm{n}$ chromosome complement of 42 or 44 . Molecular and cytogenetic analyses have shown that BYDV resistance genes are located on a $T$. intermedium group 7 chromosome that was introgressed into wheat either as a substitution for 7D $(2 n=42)$ or as an additional chromosome pair $(2 n=44)(32)$. Their study also demonstrated that this resistance could be retained in backcross derivatives. Cauderon et al. (4) also generated a line called L1, which contains a single additional group 7 chromosome from $T$. intermedium and is resistant to BYDV $(1,2,17)$. Sharma et al. (32), through restriction fragment length polymorphism (RFLP) analysis, indicated that the wheatgrass chromosome in L1 was different from that contained in the lines they developed.

The BYD virus originally was classified into four strains (PAV, MAV, RPV, and RMV) on the basis of vector specificity, host range, and virulence (28). BYDV strains were then divided into two subgroups based upon cytopathology (11), which has since been confirmed by their serological relationships, genome organization, and sequence divergence $(30,38)$. Subgroup I contains PAV, MAV, and SGV, and subgroup II contains RPV and RMV (37). The PAV strain appears to be the most prevalent strain worldwide $(7,39)$, although recent data indicates that, in central Indiana, RPV is now quite common (K. L. Perry, unpublished data). The strain(s) that predominates in a particular location differs within countries and continents and can also change over time $(29,39)$. As a result of this dynamic situation, BYDV-resistant germ plasm that is released for cultivar development or production must be thoroughly characterized for strain specificity and degree of effectiveness.
Publication no. P-1998-0624-01R

This article is in the public domain and not copyrightable. It may be freely reprinted with customary crediting of the source. The American Phytopathological Society, 1998. 
In this study, we characterized P29, an introgression wheat line (34) in which a T. intermedium group 7 chromosome was substituted for wheat chromosome 7D $(10,32)$, to determine the level and spectrum of BYDV resistance. Sharma et al. (32) determined that this substitution line was resistant to PAV and that the wheatgrass donor line was also resistant to RPV. This study was conducted to characterize the effectiveness of this transferred resistance to four BYDV strains, determine if this resistance was due to an inhibition of replication at the single-cell level, and determine what level of resistance contained in the donor T. intermedium is present in P29. The addition line, L1, was also examined to determine if the $T$. intermedium alien chromosomes in L1 and P29 were different.

\section{MATERIALS AND METHODS}

Plant lines. Plants of BYDV-susceptible wheat cultivar Abe (26), the introgression lines P29 and L1, and T. intermedium cultivar Oahe (gift from Curtis and Curtis, Inc., Clovis, NM) were grown in the greenhouse with a 16-h light period at either Cornell University, Ithaca, NY, or Purdue University, West Lafayette, IN. The temperature was not precisely controlled and ranged from 20 to $25^{\circ} \mathrm{C}$. P29 and L1 are wheat lines in which a $T$. intermedium group 7 chromosome was introgressed into wheat either as a substitution for $7 \mathrm{D}(2 \mathrm{n}=42)$ or as an additional chromosome $(2 \mathrm{n}=$ $44)$, respectively $(1,2,17,34)$. The plants were grown in either potting soil or sand to facilitate the recovery of roots.

Aphids and virus strains. Viruliferous aphids (Rhopalosiphum padi (Linnaeus)) were used to transmit the various BYDV strains. At Purdue University, viruliferous aphids were maintained on BYDV-susceptible oat (Avena sativa L. cv. Clintland 64) in growth chambers at $18^{\circ} \mathrm{C}$ with a $16-\mathrm{h}$ light period. Both subgroups I and II BYDV strains were transmitted by $R$. padi. To maintain a supply of viruliferous aphids, healthy oat plants at the two- to fourleaf stage were placed in growth chambers at 2-week intervals and infested with viruliferous aphids. At Cornell University, nonviruliferous aphids fed on infected oat plants (cv. Coast Black) for $48 \mathrm{~h}$ to allow the aphid to acquire the virus, and these viruliferous aphids were then transferred to the test plants for inoculation.

The virus strains used were two subgroup I strains, P-PAV (36) and 129-PAV (5), and two subgroup II strains, NY-RPV and NY-RMV (28). The 129-PAV strain was used because it is a virulent isolate that produces pronounced symptoms in otherwise tolerant oat lines (5). The BYDV strains 129-PAV and NY-RMV were maintained at Cornell University, and inoculations with these strains were performed at Cornell. The P-PAV and NY-RPV strains were maintained and used as inoculum at Purdue University.

Virus transmission. Plants at the three- to four-leaf stage were infested with viruliferous $R$. padi aphids. At Purdue University, viruliferous aphids were sprinkled on test plants randomly arranged in trays in growth chambers. These plants were examined after 5 to $6 \mathrm{~h}$ to insure that 5 to 10 aphids per plant were feeding on all the test plants. Additional aphids were added as needed to assure that inoculation occurred. At Cornell University, 10 viruliferous aphids were transferred to each plant. In all cases, the aphids were killed with the insecticide malathion after feeding for 2 days. The plants were allowed to grow for 2 or 3 additional weeks in the greenhouse, at which time the entire plant was harvested and stored at $4^{\circ} \mathrm{C}$ for 1 to 2 days until the enzyme-linked immunosorbent assay (ELISA) used for virus detection and titer could be performed. Plants inoculated at Cornell University were harvested and shipped overnight on ice to Purdue University for analysis.

Virus detection. The harvested plants were dissected just above the crown for separate ELISA measurements of the roots and shoots. The plant tissue was weighed and extracted with 1:10 $\mathrm{wt} / \mathrm{vol}$ of phosphate-buffered saline (PBS) (pH 7.4, $140 \mathrm{mM} \mathrm{NaCl}$, $2.7 \mathrm{mM} \mathrm{KCl}, 8.1 \mathrm{mM} \mathrm{Na}_{2} \mathrm{HPO}_{4}$, and $1.5 \mathrm{mM} \mathrm{KH}_{2} \mathrm{PO}_{4}$ ) using a roller press (model 1; Ravenel Specialties, Seneca, SC). Virus was detected in the plant exudate by a double-antibody sandwich ELISA (DAS-ELISA) as previously described $(6,16)$. Antiserum specific for each BYDV strain was used. P-PAV antiserum recognized both strains of PAV used in this study (P-PAV and 129-PAV). The ELISA optical density readings were measured with a microtiter plate reader (model MR 600; Dynatech Laboratories, Inc., Alexandria, VA) in dual wavelength mode at 410 and $630 \mathrm{~nm}$. The para-nitrophenol chromophore was measured at $410 \mathrm{~nm}$, and plate imperfections were corrected by measuring at $630 \mathrm{~nm}$ (MR 600 operating manual).

Isolation and inoculation of protoplasts with NY-RPV. NYRPV virions were isolated as described by Hammond et al. (16). Protoplasts were isolated from P29 and 'Abe' seedlings 9 days after planting. Leaf tissue was minced and submerged in a solution containing $2 \%$ cellulysin (Calbiochem, San Diego, CA), $0.1 \%$ macerase (Calbiochem), $10 \%$ mannitol, and $0.1 \%$ bovine serum albumin, and the protoplasts were released as described by Okuno and Furusawa (25). The protoplasts (approximately $1 \times 10^{6}$ ) were inoculated with $0.6 \mu \mathrm{g}$ of NY-RPV virions using a polyethylene glycol (PEG) solution (40\% PEG and $3 \mathrm{mM} \mathrm{CaCl}_{2}$ ) (18). Inoculated protoplasts were incubated for $48 \mathrm{~h}$ at room temperature in protoplast medium (Murashige and Skoog basal medium, 10\% mannitol). Following incubation, the protoplasts were harvested by centrifugation at $75 \times g$, resuspended in $50 \mu \mathrm{l}$ of protoplast medium, and approximately 125 to 150 protoplasts were mounted on glass slides. Slides were treated in acetone for $1 \mathrm{~h}$ at room temperature, air-dried, and rinsed in PBS (140 mM NaCl, $2.5 \mathrm{mM} \mathrm{KCl}$,

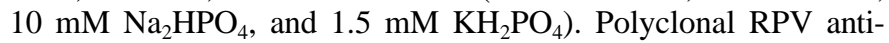
bodies were added to the mounted protoplasts at a dilution of 1:100 in PBS, incubated in a humidity chamber for $1 \mathrm{~h}$ at room temperature, and the slides washed in PBS for $15 \mathrm{~min}$. Fluorescein isothiocyanate-conjugated mouse anti-rabbit immunoglobulin G (Sigma Chemical Co., St. Louis) was added at a dilution of 1:72, and the slides were incubated for $1 \mathrm{~h}$ in the dark in a humidity chamber at room temperature and washed in PBS for $15 \mathrm{~min}$. Immunofluorescence microscopy was used to identify infected protoplasts, and fluorescent (infected) and nonfluorescent (uninfected) protoplasts were counted. For each PEG inoculation, five to six protoplast samples were mounted and analyzed for virus replication. An analysis of variance was conducted on the arcsin transformation of the ratio of infected/uninfected protoplasts. The experiment $\times$ line, experiment $\times$ virus, and experiment $\times$ line $x$ virus interaction terms were nonsignificant and were then pooled with the error term. The $F$ values of the remaining sources of variation were calculated using this pooled variance. The numbers of infected protoplasts were averaged over the number of samples analyzed. To determine the ability of the protoplasts to support virus replication, brome mosaic virus (BMV) was used as an inoculum following the above procedure and detected using antiserum specific for BMV kindly provided by S. Loesch-Fries, Purdue University.

Detection of a telomere-specific sequence in substitution lines P29 and L1. Genomic DNAs from seedlings of P29, L1, T. intermedium, and two parental wheat lines of P29 (Clark and 81401) were isolated as described (10). These genomic DNAs (25 ng) were denatured in $500 \mu \mathrm{l}$ of $0.4 \mathrm{M} \mathrm{NaOH}$ and blotted to Hybond $\mathrm{N}+$ (Amersham Corp., Arlington Heights, IL) using a slot-blot apparatus (Schleicher \& Schuell, Inc., Keene, NH) as described in the operations manual. This DNA was fixed to the membrane by baking at $80^{\circ} \mathrm{C}$ for $1 \mathrm{~h}$, prehybridized, hybridized with pAW161, and the excess nonspecifically bound probe removed as described by Francki et al. (10). P. Langridge (University of Adelaide, Adelaide, Australia) kindly provided the rye clone pAW161 (15), which is a member of the 350 - to 480 -bp rye telomeric repetitive family. This repetitive element specifically binds to the long arm telomere of the group $7 \mathrm{~T}$. intermedium chromosome contained in P29 (9). 


\section{RESULTS}

Level and spectrum of resistance in P29. The P-PAV virus titer in P29 ranged from 130 to $74 \%$ and 50 to $42 \%$ in root and shoot tissue, respectively, compared with 'Abe', while there was no detectable virus present in T. intermedium (Table 1). In contrast, NY-RPV was not detected in either P29 or the wheatgrass T. intermedium. These results indicate that the high degree of NY-RPV resistance contained in T. intermedium was transferred to P29, whereas only partial resistance to PAV was transferred to P29.

To determine if these different degrees of resistance extended to other BYDV strains, a separate experiment (Table 1, experiment 2) was performed in which four different BYDV strains were used as inoculum. Two of these strains are classified as subgroup I (P-PAV and 129-PAV) and two are classified as subgroup II (NY-RPV and NY-RMV). Compared with the susceptible cultivar Abe, P-29 was moderately resistant to subgroup I PAV strains, having 52 to $42 \%$ of the virus titer in shoot tissue (Table 1). These data also show that, in shoot tissue, P29 is completely resistant to the subgroup II strains NY-RMV and NY-RPV.

The moderate resistance to subgroup I PAV strains observed in shoot tissue of P29 was not evident in roots. Virus was not detected in either shoot or root tissue of T. intermedium (Table 1). Subgroup II strains were not detected in the shoots (everything above the crown) or roots (the crown and below) of P29 plants (Table 1).

Replication of NY-RPV in protoplasts. To further analyze the resistance to subgroup II strains, NY-RPV virions were used to inoculate 'Abe' and P29 protoplasts isolated from 1-week-old shoot tissue. Following PEG inoculation and incubation in the dark for $48 \mathrm{~h}$, the presence of RPV was determined by fluorescence microscopy. The lack of detectable virions immediately following inoculation, as observed in preliminary experiments, shows that the fluorescence observed was due to viral replication and not detection of the input virions. As a control to insure that 'Abe' and P29 protoplasts were competent in virus inoculation and replication, BMV was used as an inoculation and ELISA control using BMV-specific antiserum. In these experiments, both BMV and NY-RPV infected comparable numbers of protoplasts of P29 and 'Abe' (Table 2). This suggests that the resistance to subgroup II strains and specifically NY-RPV is not due to an inhibition of replication in single cells, but is manifested at the tissue or whole plant level.

Differentiation of the wheatgrass chromosome in P29 from that in L1. L1 is an alien addition wheat line that, like P29, contains a $T$. intermedium group 7 chromosome $(1,2,17,41)$. The results in Table 3 and previous studies $(2,17)$ show that L1 and L1-de- rived translocation lines have subgroups I and II resistance properties similar to P29. To determine if the same $T$. intermedium chromosome had been introgressed into both P29 and L1, DNA from these two lines were hybridized with a probe previously shown to specifically hybridize to the long arm telomere of the $T$. intermedium chromosome in P29 (10). The dot blot hybridization (Fig. 1) shows that this probe does not hybridize to wheat or L1 genomic DNA. This lack of hybridization suggests that the group 7 chromosomes in P29 and L1 are different.

\section{DISCUSSION}

All attempts to find substantial resistance to BYDV in wheat have failed. Several laboratories have, therefore, undertaken to transfer the BYDV resistance in wheatgrass to wheat $(2,17,32,40)$. In this study, we have shown that $T$. intermedium, the BYDV resistance donor used for integration of BYDV resistance into wheat, is completely resistant throughout the plant to both subgroups I and II strains. Sharma et al. $(32,34)$ introgressed alien chromatin from $T$. intermedium into wheat and selected those lines that showed resistance to BYDV. Now that this transfer has been achieved, it is important to determine the degree and spectrum of resistance transferred from wheatgrass to wheat introgression lines. We chose to investigate P29, an alien substitution line that appeared to be resistant to P-PAV, a subgroup I isolate (34). This line was partially resistant to P-PAV and 129-PAV. In shoot tissue, the virus titer was reduced by 42 to $52 \%$ when compared with the titer in shoot tissue of 'Abe', the susceptible check. 129-PAV is a BYDV subgroup I PAV strain isolated from maize in New York that causes much more severe disease and yield loss in various oat lines than other PAV strains including P-PAV (5). Also, the nucleotide sequence identity of the capsid protein gene of 129-PAV compared with that of P-PAV is $87 \%$, which is significantly lower than the 98 to $97 \%$ sequence identity of P-PAV with the NY-PAV and Vic-PAV isolates from New York and Victoria, Australia, respectively. However, when the virus titer in roots was examined, it was evident that P29 was completely susceptible to both subgroup I PAV strains. The high titer did not correlate with a reduction in the fresh weight of the corresponding seedling tissue compared with 'Abe', the susceptible control (data not shown). These data demonstrate that only part of the resistance to subgroup I PAV strains possessed by T. intermedium was transferred to P29. Upon inoculation of the plant by viruliferous aphids, the virus can readily move to and replicate in the root tissue.

There are several studies of another wheat line (L1) and its derivatives that also contain an introgressed $T$. intermedium group 7

TABLE 1. Determining the level and spectrum of wheatgrass-derived barley yellow dwarf virus resistance in Abe, a susceptible wheat cultivar, and P29, a resistant alien substitution line

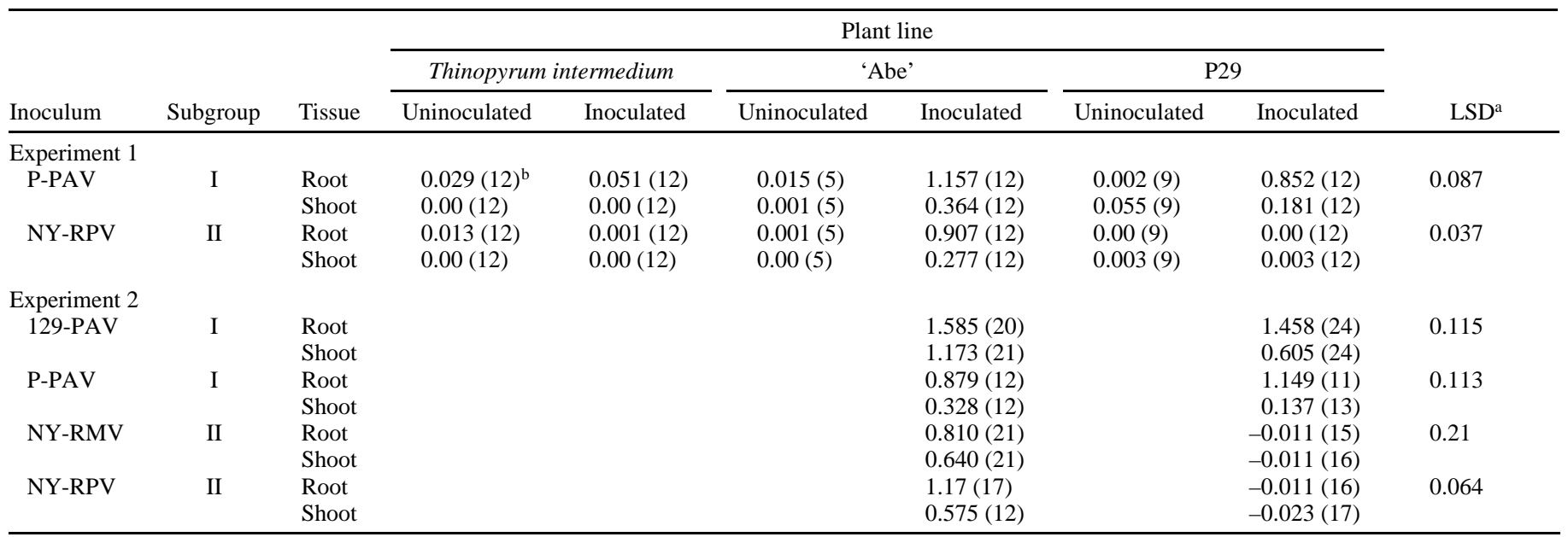

a Least significant difference (LSD) of root and shoot at the 5\% confidence level for differences between plant lines.

b The average enzyme-linked immunosorbent assay (ELISA) value based upon ( $n$ ), the number of plants analyzed by ELISA. 
chromosome $(1,2,17,41)$ and are resistant to PAV (subgroup I) strains. Our results indicate that the degree of resistance in L1 to subgroups I and II strains is the same as that contained in P29 (Table 3). Southern blot hybridization analysis using a probe that is specific for the long arm telomere of the wheatgrass chromosome in P29 (10) suggests that the wheatgrass group 7 chromosome in L1 is different from the wheatgrass group 7 chromosome in P29. This supports the conclusions of Sharma et al. (32) based on RFLP analysis that indicated that the wheatgrass chromosome in L1 is a different group 7 chromosome from that contained in P29 and other related Purdue University BYDV resistant lines. It is possible that the wheatgrass chromosome contained in L1, which was also introgressed from hexaploid (EEEEStSt) T. intermedium, has lost this telomere. However, this is probably not the case, because fluorescence in situ hybridization analysis of $T$. intermedium, using pAW161 as a probe, revealed that some T. intermedium chromosomes do not contain this telomere repeat and others either have this repeat at one chromosome end or at both ends (M. G. Francki and J. M. Anderson, unpublished data). Zhang et al. (41) demonstrated that the wheatgrass chromosome in L1 is from the St genome and not the E genomes, although their data also shows that this chromosome does contain some E genome DNA in the centromeric region. Although this illustrates the possibility of rearrangements between homoeologous chromosomes of different genomes, the RFLP data of Sharma et al. (32) and the results of this study strongly suggest that the wheatgrass chromosome in P29 is most likely from one of the T. intermedium E genomes. This is supported by the fact that 38 accessions of Elytriga elongata (EE), 6 accessions of Agropyron ponticum (decaploid E), and 17 accessions of T. elongatum (EE) originally collected from such diverse locations as Turkey, the former Soviet Union, Portugal, Iran, the Russian Federation, Morocco, Tunisia, and China also have complete resistance to BYDV PAV and NY-RPV (data not shown). P29 was crossed to L1 and, following inoculation with P-PAV, the F1 progeny had the same level of resistance as L1 and $\mathrm{P} 29$, indicating that the $\mathrm{L} 1$ and P29 resistance is not additive

TABLE 2. Replication of barley yellow dwarf virus strain NY-RPV in protoplasts of the resistant (P29) and susceptible ('Abe') wheat lines

\begin{tabular}{llcc}
\hline & & \multicolumn{2}{c}{ Plant line } \\
\cline { 4 - 4 } Experiment $^{\mathrm{a}}$ & Inoculum $^{\mathrm{b}}$ & 'Abe' & $\mathrm{P} 29$ \\
\hline 1 & $\mathrm{BMV}$ & $49 / 126^{\mathrm{d}}$ & $35 / 121$ \\
& $\mathrm{NY}-\mathrm{RPV}$ & $26 / 126$ & $33 / 121$ \\
2 & $\mathrm{BMV}$ & $31 / 135$ & $33 / 143$ \\
& $\mathrm{NY}-\mathrm{RPV}$ & $16 / 135$ & $19 / 143$ \\
\hline
\end{tabular}

${ }^{\mathrm{a}}$ In each experiment, aliquots of the inoculated protoplasts were analyzed for the presence of virus. In experiments 1 and 2, five and six aliquots, respectively, were examined for virus.

$\mathrm{b}$ Virus strain used to inoculate the protoplasts.

${ }^{\mathrm{c}}$ Control inoculation with brome mosaic virus (BMV) to determine the ability of the protoplasts to support virus replication.

${ }^{d}$ The average number of protoplasts positive for virus replication/number of protoplasts examined.

TABLE 3. Comparison of the level of wheatgrass-derived resistance in the alien substitution line P29 and the alien addition line L1

\begin{tabular}{|c|c|c|c|c|c|}
\hline \multirow[b]{3}{*}{ Inoculum } & \multirow[b]{3}{*}{ Tissue } & \multicolumn{4}{|c|}{ Plant line } \\
\hline & & \multicolumn{2}{|c|}{ P29 } & \multicolumn{2}{|c|}{ L1 } \\
\hline & & Uninoculated & $\overline{\text { Inoculated }}$ & Uninoculated & Inoculated \\
\hline \multirow[t]{2}{*}{ P-PAV } & Roo & $0.060(3)^{b}$ & 1 & 0.0 & $1.242(5)$ \\
\hline & Shoot & $0.004(3)$ & $0.023(5)$ & $-0.002(2)$ & $0.102(5)$ \\
\hline \multirow[t]{2}{*}{ NY-RPV } & Root & $0.017(3)$ & $0.059(5)$ & $0.014(2)$ & $0.067(5)$ \\
\hline & Shoot & $-0.012(3)$ & 0.005 (5) & $-0.014(2)$ & $0.034(5)$ \\
\hline
\end{tabular}

${ }^{a}$ The least significant difference (LSD) at the $5 \%$ confidence level is 0.189 for P-PAV and 0.074 for NY-RPV.

${ }^{\mathrm{b}}$ The average enzyme-linked immunosorbent assay (ELISA) value based upon $(n)$, the number of plants analyzed by ELISA. (data not shown). In summary, these results suggest that the subgroup I resistance is oligo- or polygenic with additional resistance genes on chromosomes other than group 7 chromosomes and that BYDV resistance is not confined to the St genome as previously suggested (41).

Although these greenhouse studies demonstrate that there is a significant level of virus in P29 shoot tissue, preliminary studies have indicated that P29 does exhibit resistance to PAV in field plots (34). A possible explanation for this resistance is that the $50 \%$ reduction in the PAV titer decreased transmission frequency and disease incidence. Gray et al. (14) have shown that BYDV disease incidence is lowered when there is a reduction in virus titer. It appears that the reduction in titer resulted in a lower transmission efficiency and subsequent decrease in disease incidence. Other studies by Gray et al. (13) and Pereira et al. (27) also suggested that the virus content played an important role in the transmission of the virus. However, other factors such as aphid vector, age of source tissue, and length of the acquisition time also had a strong effect on transmission. Currently, work is underway to determine if the lower PAV titer found in P29 will reduce virus transmission and disease incidence in both greenhouse and field analyses.

In contrast to the results obtained with subgroup I strains, the complete resistance to subgroup II strains contained in $T$. intermedium has been incorporated into P29. NY-RMV and NYRPV were not detected in either shoot or root tissue. Likewise, P29 was completely resistant to a RPV strain recently isolated in Indiana (data not shown). The genomic organization of subgroup I strains is quite different from that of subgroup II strains. The subgroup II strains are most similar in genomic organization and coat protein nucleotide sequence to other luteoviruses such as beet western yellows virus (65\% sequence identity) and potato leaf roll virus (69\% sequence identity); the sequence identity to subgroup I strain P-PAV is only 56\% (37). These differences between subgroups I and II BYDV strains may account for the specificity of the complete resistance to subgroup II strains.
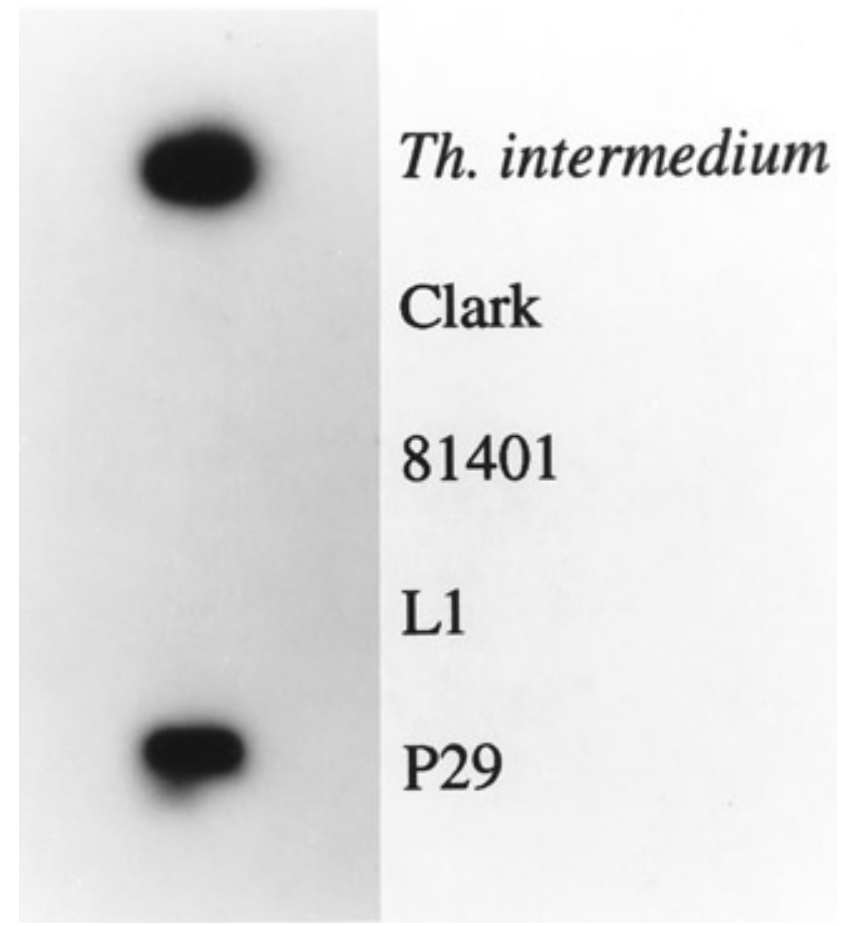

Fig. 1. Detection of a telomere-specific sequence in wheatgrass, wheat, and wheat substitution lines by slot-blot hybridization. Genomic DNAs (25 ng) isolated from wheatgrass (Thinopyrum intermedium), two wheat lines (Clark and 81401) and two alien substitution lines (P29 and L1), were probed with pAW161, a telomere-specific probe that specifically hybridizes to the alien chromosome in P29 (10). 
Resistance to RPV was not observed in isolated protoplasts of P29. This suggests that this resistance is not due to a block in viral replication. BYDV is a phloem-limited virus, and it is possible that the resistance in P29 is confined to vascular tissue cells that are probably not present in the protoplasts used, as they were primarily mesophyll cells. Another explanation for this result is that the resistance is due to a block or reduction in the cell-to-cell or systemic movement of the virus that would only be observed in intact tissue. It appears that this BYDV resistance is similar to other examples of virus resistance that are not effective at the protoplast level such as $Y d 2$ in barley (20), Tm-2 in tomato (23), and Cry in cowpea (24).

\section{LITERATURE CITED}

1. Banks, P. M., Larkin, P. J., Bariana, H. S., Lagudah, E. S., Appels, R., Waterhouse, P. M., Brettell, R. I. S., Chen, X., Xu, H. J., Xin, Z. Y., Qian, Y. T., Zhou, X. M., Cheng, Z. M., and Zhou, G. H. 1995. The use of cell culture for subchromosomal introgressions of barley yellow dwarf virus resistance from Thinopyrum intermedium to wheat. Genome 38:395-405.

2. Brettell, R. I. S., Banks, P. M., Cauderon, Y., Chen, X., Cheng, Z. M., Larkin, P. J., and Waterhouse, P. M. 1988. A single wheatgrass chromosome reduces the concentration of barley yellow dwarf virus in wheat. Ann. Appl. Biol. 113:599-603.

3. Burnett, P. A., Comeau, A., and Qualset, C. O. 1995. Host plant tolerance or resistance for control of barley yellow dwarf. Pages 321-343 in: Barley Yellow Dwarf Virus: Forty Years of Progress. C. J. D'Arcy and P. A. Burnett, eds. The American Phytopathological Society, St. Paul, MN.

4. Cauderon, Y., Autran, J. C., Jondrier, P., and Kobrehel, K. 1978. Identification de chromosomes d'Agropyron intermedium impliques dans la synthase des gliadines, des b-amalyses et desperoxidases a l'aide de lignees d'addition Ble X Agropyron. Ann. Amelior. Plant. (Paris) 28:257-267.

5. Chay, C. A., Smith, D. M., Vaughan, R., and Gray, S. M. 1996. Diversity among isolates within the PAV serotype of barley yellow dwarf virus. Phytopathology 86:370-377.

6. Clark, M. F., and Adams, A. N. 1977. Characteristics of the microplate method of enzyme-linked immunosorbent assay for the detection of plant viruses. J. Gen. Virol. 34:475-483.

7. Clement, D. L., Lister, R. M., and Foster, J. E. 1986. ELISA-based studies on the ecology and epidemiology of barley yellow dwarf virus in Indiana. Phytopathology 76:86-92.

8. Comeau, A., and Plourde, A. A. 1987. Cell, tissue culture and intergeneric hybridization for barley yellow dwarf virus resistance in wheat. Can. J. Plant Pathol. 9:188-192.

9. D'Arcy, C. J. 1995. Symptomology and host range of barley yellow dwarf. Pages 9-28 in: Barley Yellow Dwarf Virus: Forty Years of Progress. C. J. D'Arcy and P. A. Burnett, eds. The American Phytopathological Society, St. Paul, MN.

10. Francki, M. G., Crasta, O., Anderson, J. M., Sharma, H., and Ohm, H. W. 1997. Structural organization of an alien Thinopyrum intermedium group 7 chromosome in US soft red winter wheat (Triticum aestivum L.). Genome 40:716-722.

11. Gill, C. C., and Chong, J. 1979. Cytopathological evidence for the division of barley yellow dwarf virus isolates into two subgroups. Virology 95:59-69.

12. Gourmet, C., Kolb, F. L., Smyth, C. A., and Pedersen, W. L. 1996. Use of imidacloprid as a seed-treatment insecticide to control barley yellow dwarf virus (BYDV) in oat and wheat. Plant Dis. 80:136-141.

13. Gray, S. M., Power, A. G., Smith, D. M., Seaman, A. J., and Altman, N. S. 1991. Aphid transmission of barley yellow dwarf virus: Acquisition access periods and virus concentration requirements. Phytopathology 81:539-545.

14. Gray, S. M., Smith, D. M., and Sorrels, M. 1994. Reduction of disease incidence in small field plots by isolate-specific resistance to barley yellow dwarf virus. Phytopathology 84:713-718.

15. Guidet, F. L. Y., Rogowsky, P. M., Taylor, C., Weining, S., and Langridge, P. 1991. Cloning and characterization of a new rye-specific repeated sequence. Genome 34:81-87.

16. Hammond, J., Lister, R. M., and Foster, J. E. 1983. Purification, identity and some properties of an isolate of barley yellow dwarf virus from Indiana. J. Gen. Virol. 64:667-676.

17. Hohmann, U., Badaeva, K., Busch, W., Friebe, B., and Gill, B. S. 1996. Molecular cytogenetic analysis of Agropyron chromatin specifying resistance to barley yellow dwarf virus in wheat. Genome 39:336-347.

18. Kroner, P., Richards, D., Traynor, P., and Ahlquist, P. 1989. Defined mutations in a small region of the brome mosaic virus 2a gene cause diverse temperature-sensitive RNA replication phenotypes. J. Virol. 63:
5302-5309.

19. Larkin, P. J., Banks, P. M., Lagudah, E. S., Appels, R., Chen, X., Xin, Z., Ohm, H. W., and McIntosh, R. A. 1995. Disomic Thinopyrum intermedium addition lines in wheat with barley yellow dwarf virus resistance and with rust resistance. Genome 38:385-394.

20. Larkin, P. J., Young, M. J., Gerlach, W. L., and Waterhouse, P. M. 1991. The Yd2 resistance to barley yellow dwarf virus is effective in barley plants but not in their leaf protoplasts. Ann. Appl. Biol. 118: 115-125.

21. Lister, R. M., and Ranieri, R. 1995. Distribution and economic importance of barley yellow dwarf. Pages 29-53 in: Barley Yellow Dwarf Virus: Forty Years of Progress. C. J. D'Arcy and P. A. Burnett, eds. The American Phytopathological Society, St. Paul, MN.

22. McKirdy, S. J., and Jones, R. A. C. 1996. Use of imidacloprid and newer generation synthetic pyrethroids to control the spread of barley yellow dwarf luteovirus in cereals. Plant Dis. 80:895-901.

23. Motoyoshi, F., and Oshima, N. 1977. Expression of genetically controlled resistance to tobacco mosaic virus infection in isolated leaf mesophyll protoplasts. J. Gen. Virol. 34:499-506.

24. Nasu, Y., Karasawa, A., Hase, S., and Ehara, Y. 1996. Cry, the resistance locus of cowpea to cucumber mosaic virus strain Y. Phytopathology 86: 946-951.

25. Okuno, T., and Furusawa, I. 1977. A simple method for the isolation of intact mesophyll protoplasts from cereal plants. Plant Cell Physiol. 18: 1357-1362.

26. Patterson, F. L., Gallun, R. L., Roberts, J. J., Finney, R. E., and Shaner, G. E. 1975. Registration of Arthur-71 and Abe wheat. Crop Sci. 15:736.

27. Pereira, A.-M. N., Lister, R. M., Barbara, D. J., and Shaner, G. E. 1989. Relative transmissibility of barley yellow dwarf virus from sources with differing virus contents. Phytopathology 79:1353-1358.

28. Rochow, W. F. 1969. Biological properties of four isolates of barley yellow dwarf virus. Phytopathology 59:1580-1589.

29. Rochow, W. F. 1979. Field variants of barley yellow dwarf virus: Detection and fluctuation during twenty years. Phytopathology 69:655660.

30. Rochow, W. F., and Carmichael, L. E. 1979. Specificity among barley yellow dwarf viruses in enzyme immunosorbent assays. Virology 95:415-420.

31. Sharma, H. C., Gill, B. S., and Uyemoto, J. K. 1984. High levels of resistance in Agropyron species to barley yellow dwarf and wheat streak mosaic viruses. Phytopathol. Z. 110:143-147.

32. Sharma, H. C., Ohm, H., Goulart, L., Lister, R., Appels, R., and Benlhabib, O. 1995. Introgression and characterization of barley yellow dwarf virus resistance from Thinopyrum intermedium into wheat. Genome 38:406-413.

33. Sharma, H. C., Ohm, H. W., Lister, R. M., Foster, J. E., and Shukle, R. H. 1989. Response of wheatgrasses and wheat $\times$ wheatgrass hybrids to barley yellow dwarf virus. Theor. Appl. Genet. 77:369-374.

34. Sharma, H. C., Ohm, H. W., and Perry, K. L. 1997. Registration of barley yellow dwarf virus resistant wheat germplasm line P29. Crop Sci. 37: 1032-1033.

35. Shukle, R. H., Lampe, D. J., Lister, R. M., and Foster, J. E. 1987. Aphid feeding behavior: Relationship to barley yellow dwarf virus resistance in Agropyron species. Phytopathology 77:725-729.

36. Ueng, P. P., Vincent, J. R., Kawata, E. E., Lei, C.-H., Lister, R. M., and Larkins, B. A. 1990. Nucleotide sequence analysis of the MAVPS1 and P-PAV isolates of barley yellow dwarf virus. J. Gen. Virol. 73:487-492.

37. Vincent, J. R., Lister, R. M., and Larkins, B. A. 1991. Nucleotide sequence analysis and genomic organization of the NY-RPV isolate of barley yellow dwarf virus. J. Gen. Virol. 72:2347-2355.

38. Vincent, J. R., Ueng, P. P., Lister, R. M., and Larkins, B. A. 1990. Nucleotide sequences of coat protein genes of three isolates of barley yellow dwarf virus and their relationships to other luteovirus coat protein sequences. J. Gen. Virol. 71:2791-2799.

39. Webby, G. N., Lister, R. M., and Burnett, P. A. 1993. The occurrence of barley yellow dwarf viruses in CIMMYT bread wheat nurseries and associated cereal crops during 1988-1990. Ann. Appl. Biol. 123: 63-74.

40. Xin, Z. Y., Brettell, R. I. S., Cheng, Z. M., Waterhouse, P. M., Appels, R., Banks, P. M., Zhou, G. H., Chen, X., and Larkin, P. J. 1988. Characterization of a potential source of barley yellow dwarf virus resistance for wheat. Genome 30:250-257.

41. Zhang, X. Y., Koul, A., Petroski, R., Ouellet, T., Fedak, G., Dong, Y. S., and Wang. R. R.-C. 1996. Molecular verification and characterization of BYDV-resistant germplasms derived from hybrids of wheat with Thinopyrum ponticum and Th. intermedium. Theor. Appl. Genet. 93:1033-1039. 